\title{
Can the Office Environment Be a Motivator? What Makes a Good Enough Working Environment on the Eve of 2020?
}

\author{
Luca Frankó1*, Andrea Dúl|2,3 \\ 1 Doctoral School of Psychology, ELTE Eötvös Loránd University, Budapest, H-1064 Budapest, Izabella str. 46., Hungary \\ 2 Institute of Psychology, ELTE Eötvös Loránd University, Budapest, H-1064 Budapest, Izabella str. 46., Hungary \\ ${ }^{3}$ Department of Sociology and Communications, Faculty of Economic and Social Sciences, \\ Budapest University of Technology and Economics, H-1521 Budapest, P.O.B. 91, Hungary \\ *Corresponding author, e-mail: franko.luca@ppk.elte.hu
}

Received: 27 March 2019, Accepted: 05 July 2019, Published online: 07 December 2019

\begin{abstract}
A well-designed office environment is often touted as a key motivator nowdays, although it is not entirely clear how to use it consciously. Our goal was to understand the role of the physical environment in new generation offices and whether it can be a motivator at all. We asked open-office employees to describe the three main criteria of an excellent work environment. We analyzed 509 participants' 1456 answers and classified them into 146 content codes. These content codes were further categorized based on whether they refer to the physical or/and the social environment, as well as along the eight needs Maslow described. $82.07 \%$ of the answers referred to the physical environment, ambient stimuli dominated the sample with 324 mentions under 6 content codes (eg.: bright (128), quiet (69)). The majority (55.59 \%) of the responses could be categorized under Maslow's safety needs, but $14.15 \%$ of them referred to one of Maslow's growth needs (eg.: plants (26), decoration (21)). Using the intersection of Maslow's and Herzberg's theory, we argue that certain physical environmental aspects can be considered as a hygiene factor, some of them as a motivator. And some of them as both meaning some aspects can be considered on more level from an emotional-motivational perspective. Planning an office is not just an architectural question, but a psychological one as well. In order to design human-focused work places we need to understand the exact role and the layering of the physical environmental aspects.
\end{abstract}

\section{Keywords}

environmental psychology, office environment, new generation offices, motivation

\section{Introduction}

The office as a system (Dúll and Tauszik, 2006) has undergone radical changes several times in history and we are probably facing one such transformation at the moment as well. Over the past few years the business trend of more open and flexible organizations has emerged worldwide (JLL Research, 2019). This shift is present in both the social and the physical environment of the organization. In the best case, these two run in parallel, in close association with each other (cf. Dúll, 2009). One of the drivers behind this transformation is the need to adapt to a constantly changing external (social and physical) environment. This adaptation requires a more efficient and sustainable operation. The other driving force is the fight for the most

\footnotetext{
1 The research was partly carried out in the framework of the ELTE Higher Education Institution Excellence Program (1783-3 / 2018 / FEKUTSRAT) with the support of the Ministry of Human Capacities.
}

talented employees. The nature of the work and work tools have changed a lot over the past decade, therefore classical office systems are becoming more and more outdated. Under classical systems we mean layouts in which each employee has their own office or workstation, and usually performs their tasks at their own space during fixed working hours. The era of stationary work spaces for example is probably drawing to an end (Vischer and Wifi, 2017; JLL Research, 2019). Businesses transitioning to so-called new generation office spaces and operations will rearrange their priorities: flexibility, sustainability, and adaptability will be in focus (Fox, 2019). We experience that employers starts to behave as service providers, and physical environment starts to play an increasing role in the service portfolio. This transformation of the office design is not just an architectural question though, but a psychological one. 
For example we do not know exactly how physical environmental elements fit in the motivational systems and how to "use" them consciously. But this is not just the issue of the scientists either, but the employers' and the space users' as well (cf. Alexander et al., 1977). We argue that participatory planning is crucial not only for primary territories (cf. Dúll, 2009), but also for public spaces (cf. Dúll and Pálfy, 2014). The next generation offices will be somewhere between those two, closer to one end or the other of this dimension depending on the details of the implementation. The intention of action can be perceived. In order for the psychologically correct course of action to be identified, two important aspects must be considered. First, based on the psychology of classical office systems we can formulate and test hypotheses about the new generation system. Second, we must investigate the needs of the employees in the light of the changes in order to understand better the role of the physical environment, for example from an emotional-motivational perspective.

\section{Literature review}

\subsection{Psychological aspects of employee spatial use - what we already know about classical office systems}

Many scientists of many disciplines have investigated the circumstances in which employees are able to work effectively and efficiently (eg. Salama and Courtney, 2013). In environmental psychological office studies the main focus was often the comparison of the enclosed and the open office designs. Based on the results, enclosed offices seem to be a better solution for most employees due to the chance for higher levels of personalization, the lower noise levels or the greater privacy these enclosed spaces afford (Laurence et al., 2013; Oldham, 1988; Oldham and Fried, 1987). Despite this, open offices have become the dominant office space design for today. It is almost certain, that employers will not return to enclosed systems, because that would go totally against the latest trends. Inversely, office spaces will become even more open and flexible in the future, therefore new hypotheses and recommendations should be formulated respecting these new circumstances (JLL Research, 2019). The rich ergonomic and psychological material about the effects of ambient stimuli can be easily implemented in new generation office systems. Studies generally emphasize the importance of noise level, temperature, and lighting. It is important to mention that in terms of noise level and lighting the demands are clear. The quieter and brighter the office is, the more employees consider it right for efficient work. The size and proximity of the windows correlate with both satisfaction with the work environment and the employer. The availability of windows is also associated with the amount and quality of sleep (Yildirim et al., 2007). Oldham and Fried (1987) described that the darker the environment is, employees tend to leave the office during the workday, and the organization within 24 months more likely. Noisy environments have been shown to degrade reading performance and reminiscence of social stimuli, as well as reduce the ability to help others (Dúll, 2009). Demands around temperature are much more complex, the ideal degree for working efficiently varies greatly by gender and the individual (Veitch et al., 2007). It is very important to find a right balance though: too low experienced temperature can lead to aggression, too high can cause apathy (Cao and Wei, 2005). The role of ambient stimuli in office environments is clearly critical, but their perception by users is not completely clear. Literature often emphasizes that these aspects are difficult to become aware of (Campbell, 1983), therefore satisfaction or dissatisfaction with the space is not necessarily associated with any of the ambient stimuli (cf. Dúll, 2009). The issue of overcrowding or interruption goes beyond ambient stimuli, but relates closely. The literature about the sense of overcrowding says it may result in higher rates of employee fluctuation and lower levels of performance (cf. Dúll, 2009). It can be considered a risk factor for high blood pressure as well (Oldham, 1988). A crowded office is not equivalent to open-plan office, overcrowding always pertains to the density of the workstations. A research by Kim and de Dear (2013) indicates that satisfaction with the amount of space best predicts the overall satisfaction with the working environment no matter the office type. Therefore, this aspect can be a key in new generation offices, too. It is also critical to understand how the space can support concentration and reduce interruption. Sudden, unexpected interruption can cause up to 60 to 100 minutes of downtime per day for an average, non-executive office worker (Sykes, 2001). According to a US research involving more than 2,000 people, it is difficult for employees to create effective working conditions for themselves. During an office design process compromise solutions are often made. For example people usually need to perform individual and group tasks within the same environment, which space therefore serve none of the methods entirely (Gensler Study, 2013). According to the authors of this research, in the best work environments, focused work is not sacrificed at the altar of teamwork. Where alternative spaces are available in the office, 
colleagues feel more innovative and report higher levels of performance (Gensler Study, 2013). Discussing explicitly the environmental psychological variables, we can state that our knowledge about territorial behavior, experienced privacy or workplace attachment cannot be adapted directly to the new generation systems. These aspects do not refer to the general spatial design, rather to the employees' own place within the office. The level of psychological ownership (Brown and Zhu, 2016; Frankó and Dúll, 2018), control over the access to the self (Altman, 1975; Frankó and Dúll, 2017; Laurence et al., 2013) or personalization (Wells, 2000) have a big impact on well-being and commitment. Therefore investigating these variables can be a key aspect to understand the psychological characteristics of new generation solutions. So the best practices from the classical systems can be fully or partially adapted to the office of the future. It is also important to emphasize though that the studies mentioned above are all based on quantitative methods. We argue that it is essential to review the aspects we measure from time to time through qualitative or mixed methodologies.

\subsection{The physical environment of the workplace from an emotional-motivational perspective}

The trend of aesthetic and well-designed offices started in Silicon Valley around the year 2000. Today, it has become the standard for multinational companies even in the EMEA region. Spatial design and its toolbox appear more and more often in the service palette of multinational companies. The physical environment has started to be seen as a potential motivator, and as a way to attract and retain employees. Physical environmental aspects though are not (or only slightly) integrated in the classical motivational theories, which are often the basis of corporate motivational systems. Therefore the "use" of the physical environment as a motivator can be only occasional in these cases. Its real effects are less monitored and controlled. In this paper, our aim is to try to integrate the physical environmental aspects into an emotional-motivational framework along two classical motivational theories. Herzberg's and Maslow's models are so-called demand-based systems. They are used widely in management and HR practices, despite raising many questions among scientists (BassettJones and Lloyd, 2005). According to Herzberg's two-factor theory (Herzberg et al., 1959), aspects affecting workers can be divided into two groups. The first group are the so-called hygiene factors (e.g. adequate wages, workplace safety), which by their very existence are incapable of motivating anyone. Improving hygiene factors does not cause satisfaction, but eliminates dissatisfaction. The second group includes motivators (e.g. responsibility, growth, success). The lack of motivators does not necessary cause a decline in satisfaction, but their presence may increase it. Motivation is always based on growth, and linked to concepts such as recognition, responsibility, and personal development. Herzberg says that satisfaction and dissatisfaction can be considered not as the ends of a dimension, but as two separate ones (Parde, 1990). Herzberg classified the entire physical environment as one of the hygiene factors. In effect, it can be said it was explicitly displaced by him from the group of possible motivators. However, his theory was primarily based on the need to describe factory and industrial work environments. Moreover, the model was published 60 years ago. It is a question, whether this concept can be adapted to today's office environments. Maslow - another early, highly influential theorist of human motivation - described the system of human motivators as a hierarchy of needs of five and later eight levels. According to Maslow, at each level only the unmet needs can be considered as motivators; satisfied needs are no longer motivating (Maslow, 1970). Maslow separates the deficit and growth needs in his model. The driving force behind the deficit needs (physiological, security, belonging and esteem needs) is the possibility of displacement from an unpleasant state. The driving force behind the growth needs (cognitive, aesthetic, self-actualization and transcendence needs) is the possibility of discovering and exploiting our potential (Maslow, 1970). Since its release, many scientists have criticized Maslow's theory. Primarily, the hierarchy of the described needs was challenged in that lower-level needs have to be met before the person can move to the next level (Tay and Diener, 2011). Despite the critics, the theory still serves as a popular framework of human motivation. In one of his early studies (Maslow and Mintz, 1956), Maslow says that the aesthetic quality of a room has an influence on the attitude of the people who need to perform in it. Attendees of his experiment reported higher levels of well-being while looking at human faces in an aesthetically pleasing than an aesthetically unpleasant environment. His experiment could not be reproduced later (e.g. Locasso, 1992), primarily because it is difficult to conceptualize pleasant and unpleasant aesthetic qualities. Maslow did not directly include physical environment in his model though, in his hierarchy of needs he explicitly deals with the role of the social environment. Through the example of visual stimuli we can demonstrate how certain elements of the physical 
environment can still be integrated into the different levels of his system: "visual access support needs for safety, and a variable, complex visual environment can support the need for knowledge and understanding" (Heerwagen et al., 1995:p.460). Several authors have attempted to link the theories of Herzberg and Maslow. For example, Ozguner and Ozguner (2014) examined the intersection of these two systems in a leadership theory approach (Fig. 1). They corresponded the hygiene factors and the deficit needs to each other, such as the the motivators and the growth needs. In our study, we undertake to differentiate the physical environment from the emotional-motivational aspect within the frame of these two systems. We believe physical environment can not be considered entirely as a hygiene factor but can be divided into hygiene factors and motivators with the help of Maslow's model. According to the basic theory of environmental psychology, the physical environment cannot be reduced to a one-dimensional aspect or left out of the discussion of emotional-motivational systems. This is because the environment is "an equal companion, a partner of man, and it participates in behavior transacting with the inner psychological processes" (Dúll, 2009:p.12). The spatial layout and tools surrounding a person affect the mood, health, and well-being of the user, in this case an office user. The physical environment continuously sends us messages, thus it plays an important role in higher motivational processes. Without conscious planning, it can have the opposite than desired impact on human behavior (Dúll and Urbán, 1997). Kaplan and Kaplan (1989) say that people prefer environments that support and encourage them in their current activity, and where the incoming spatial information is interesting but manageable. Of course, there is no general recipe for what this supportive, motivating environment means. Each design process therefore must be tailored to the actual environment-user transaction with the consideration its temporal, dynamic change (cf. Alexander et al., 1977).

\section{Hypothesis}

1. At least $50 \%$ of the answers will refer to the physical environment when describing an excellent working environment.

2. Ambient stimuli will appear among the criteria for an excellent work environment.

3. Need for enough space will appear among the criteria for an excellent work environment.

4. Need for concentration will appear among the criteria for an excellent work environment.

5. Need for alternative rooms will appear among the criteria for an excellent work environment.

6. Need for personalization will appear among the criteria for an excellent work environment.

7. New, not yet discussed, aspects will appear among the criteria for an excellent work environment.

8. The physical environment can be differentiated into hygienic factors and motivators.

\section{Research design}

\subsection{Purpose of the study}

Our study had a dual purpose. On the one hand, we aimed to discover the most important elements of an excellent working environment for today's employees. We were also curious to find out the proportion and the nature of the physical environmental aspects. On the other hand, we also wanted to differentiate the physical environment of

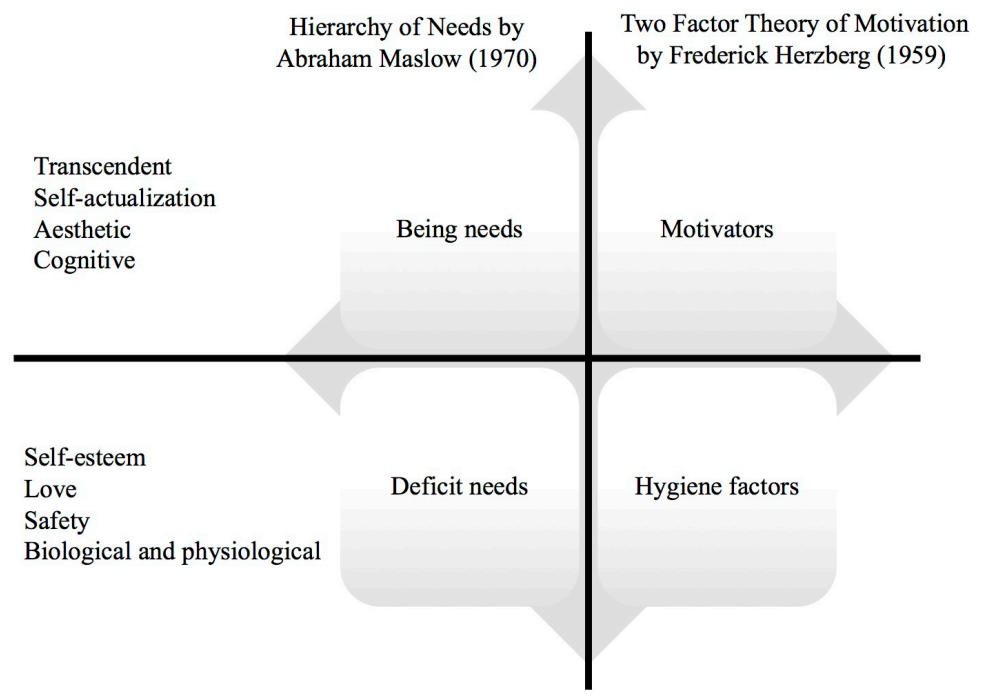

Fig. 1 Representation of the intersection of Maslow and Herzberg's motivational theory based on the work of Ozguner and Ozguner (2014) - (self edited) 
the workplace from an emotional-motivational perspective. We pursued to explore whether the physical environment can indeed be considered as a motivator in the process of recruiting and retaining employees, and if so, how.

\subsection{Sample}

In our mixed methodology exploratory study we asked open office workers: What makes an excellent working environment? We collected data during the Fittest Workplace Competition in 2016 and 2017, organized by Team Recreation Ltd. In this study, we asked the employees of 13 organizations and we received data from 509 people (260 male, 249 female). The average age was 33.6 years $(\min =20, \max =62, \operatorname{stdev}=7.48)$. All of the responders are doing office work at multinational companies in Hungary, in classical office environments with own workstations.

\subsection{Method}

For this study we used a qualitative question: What makes an excellent working environment according to you? Please write down maximum 3 criteria! Our question was sent to participants as part of the Fittest Workplace Competition Survey online questionnaire package. Our research team started to collaborate with the organizers of this competition in 2014. The goal here every year is to size up the physical, mental, and psychological fitness of the organizations entering this competition and providing them feedback on it. Since our collaboration started, environmental psychological questions have also been included in the survey. Alongside ours, employees also got questions about their well-being, sport habits, and stress management strategies. Our research group had no access to any of the questions or answers besides ours, except for knowing the age and the gender of the respondent. Organizations that enter this competition, received the online questionnaire that they then sent out to their employees. Participation was anonymous and voluntary.

\subsection{Data}

The questionnaire was available in two languages: English and Hungarian. The organization could decide which language to send, or they could send both. We did not collect information about the responders' mother tongue. Responders could name a maximum of three criteria for an excellent working environment. We received 1456 evaluable answers from 509 responders, this data set is the basis of our further analysis. $72 \%$ of the answers were in Hungarian, $28 \%$ were in English.

\subsection{Method of analysis}

For our question we asked responders to write down their top three criteria into three different table cells. The main principle of the analysis was to look for content units in the responses. If one response contained two content units we considered it as two separate items to be analyzed. For example, the "open space with friendly furniture" answer was considered as two separate items during the analysis: "open space" and "friendly furniture". We analyzed maximum three content units per person, at every case the first three of them. Responders mostly answered with one word, a combination of words or with a short sentence per table cell. Before the encoding process started, one of the encoders - the first author of this study- analyzed the responses of the first 40 participants. Based on that experience, an encoding tutorial was prepared for the other encoders. We did not deal with stylistic or any other non-content related aspects of the answers in this study.

\subsection{Encoding process}

The encoding process had three separate phases with the assistance of three encoders. All the coders were PhD students in environmental psychology, so they are considered as experts. The first phase was the creation of the content codes. All three encoders received the raw data table with 1456 responses from which content codes were generated. Only the almost identical content units could get the same code. In other words, where the content and the scope was the same. For example, clean got the same content code as cleanliness but got a different code to clean toilet. The result was only accepted when there was a $100 \%$ match between the coders. Questionable items were discussed until everyone agreed on the result. Altogether, we found a total of 146 content codes. It is important to state that we did not "created" content codes, we simple grouped and counted the (almost) identical answers. Therefore, the codes are not equally rich: there are narrower (e.g.: appropriate furniture) and broader (e.g.: ergonomic), specific (e.g.: plants) and abstract (e.g.: friendly) ones, there may also be an overlap between them.

The content codes are discussed in detail in the results section.

In the second phase, the three coders independently decided whether the previously grouped content codes referred to the physical or the social environment or maybe to both of them. As in the first phase, the result was only accepted when there was a $100 \%$ match between the three coders. Questionable items were discussed until everyone agreed on the result. 
The third phase was the most difficult part of the process, because it left the most room for subjective judgments. The three coders independently categorized the 146 content codes along Maslow's needs. The only instruction was to match content codes based on their nature and substance to the following Maslow codes (MC): biological and physiological, safety, love, self-esteem, cognitive, aesthetic, self-actualization, transcendent. A content code could only get a Maslow code when all the three coders agreed on it immediately or after a discussion. One content code could get more than one Maslow codes, all coders had to agree on all of them. The maximum number of Maslow codes a content code got here was three (e.g.: organized-safety, cognitive, aesthetic).

\section{Results}

First of all, we created a frequency table based on the content codes, we collected the top 20 in Table 1. The top five content codes turned out to be bright (128), clean (93), ergonomic (75), quiet (69) and adequate temperature (66). These frequency numbers show that there was a big agreement among responders on the most important aspects of an excellent working environment. Every fourth responder mentioned brightness, besides, another 17 people wrote natural light and 10 people mentioned windows.

$59.68 \%$ of all the answers refer to the physical environment only, and another $22.39 \%$ refer to both the physical and social environment (Fig. 2). The group with only social-environmental aspects was the smallest in terms of response numbers. This means we can accept the first hypothesis that says at least $50 \%$ of the responses refer to the physical environment of the workplace. Based on the frequency table, we can also accept the second hypothesis. All the most important ambient stimuli came up under six different content codes (bright, natural light, quiet, adequate temperature, fresh air, windows) and with 324 responses in total. We expected that need for space, need for alternative rooms, need for concentration and need for personalization would appear in the sample. According to the results the respondents actually considered these four aspects to be very important and mentioned them with high frequency and great variety. Therefore we can accept 3-6 hypotheses

Table 1 The top 20 most common aspects of an excellent working environment (self edited)

\begin{tabular}{|c|c|c|c|c|c|c|}
\hline Rank & $\begin{array}{l}\text { Content } \\
\text { Code }\end{array}$ & $\begin{array}{c}\text { Response } \\
\text { Number }\end{array}$ & $\begin{array}{c}\text { Physical/ } \\
\text { Social* }\end{array}$ & $\begin{array}{c}\text { Maslow Code } \\
1 . * *\end{array}$ & $\begin{array}{c}\text { Maslow Code } \\
2 . * *\end{array}$ & $\begin{array}{c}\text { Maslow Code } \\
\text { 3. ** }\end{array}$ \\
\hline 1 & Bright & 128 & 1 & 2 & 6 & - \\
\hline 2 & Clean & 93 & 1 & 2 & - & - \\
\hline 3 & Ergonomic & 75 & 1 & 2 & - & - \\
\hline 4 & Quiet & 69 & 3 & 2 & - & - \\
\hline 5 & $\begin{array}{l}\text { Adequate } \\
\text { temperature }\end{array}$ & 66 & 1 & 1 & 2 & - \\
\hline 6 & Comfortable & 61 & 1 & 2 & - & - \\
\hline 7 & Colleagues & 54 & 2 & 3 & - & - \\
\hline 8 & Well-equipped & 54 & 1 & 2 & - & - \\
\hline 9 & Enough space & 53 & 1 & 2 & 6 & - \\
\hline 10 & Friendly & 46 & 3 & 3 & - & - \\
\hline 11 & Good atmosphere & 46 & 3 & 3 & - & - \\
\hline 12 & $\begin{array}{l}\text { Appropriate } \\
\text { furniture }\end{array}$ & 41 & 1 & 2 & - & - \\
\hline 13 & Calm & 37 & 2 & 2 & - & - \\
\hline 14 & Fresh air & 34 & 1 & 1 & 2 & - \\
\hline 15 & Personal space & 30 & 3 & 2 & - & - \\
\hline 16 & Modern & 27 & 3 & 6 & - & - \\
\hline 17 & Plants & 26 & 1 & 6 & - & \\
\hline 18 & Organized & 24 & 3 & 2 & 6 & 5 \\
\hline 19 & Team spirit & 23 & 2 & 3 & - & - \\
\hline 20 & Decoration & 21 & 1 & 6 & & \\
\hline
\end{tabular}




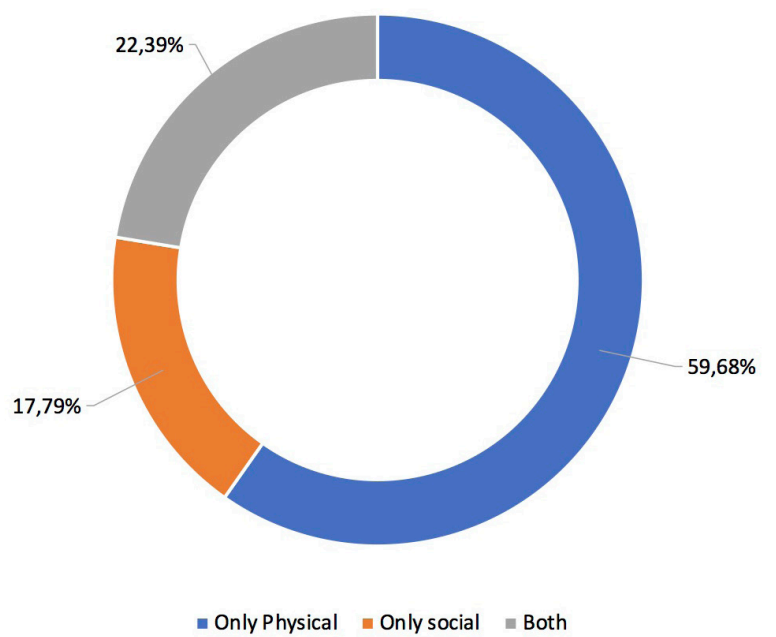

Fig. 2 Ratio between the physical and social-environmental aspects (\%) by response numbers (self edited)

as well. We identified 22 content codes, which could be attached to at least one of these four needs formulated above, which means 292 individual responses in total. Directly or indirectly 68 responses referred to the need for space, 39 to the need for alternative rooms, 190 to the need for concentration, and 52 to the need for personalization (Table 2).

Among the criteria of an excellent work environment, new or lesser-studied aspects also emerged such as cleanliness, which was the second most common response with 93 mentions. The importance of appropriate furniture, personal devices and tools were also mentioned often under many different content codes such as ergonomic (75), wellequipped (54), and appropriate furniture (41). Aesthetic aspects also seem popular, however the effect of decoration (21) or colors (18) rarely appears in the environmental psychological literature. We can accept the 7. hypothesis that lesser-studied aspects have showed up among the most frequent answers. In our research, we also undertook the task of differentiating the physical-environmental aspects of the office space from an emotional-motivational approach. We categorized all the content codes along the Maslow needs. 12 content codes received 3 Maslow codes,

Table 2 Frequency of the content codes referring to the need for space, alternative rooms, concentration and personalization (self edited)

\begin{tabular}{|c|c|c|c|c|c|}
\hline Content Codes & $\begin{array}{c}\text { Res. } \\
\text { nr. }\end{array}$ & Need for space & $\begin{array}{l}\text { Need for } \\
\text { alternative rooms }\end{array}$ & $\begin{array}{l}\text { Need for concen- } \\
\text { tration }\end{array}$ & $\begin{array}{l}\text { Need for } \\
\text { personalization }\end{array}$ \\
\hline enough space & 53 & $\mathrm{X}$ & & & \\
\hline free space & 2 & $\mathrm{X}$ & & & \\
\hline open & 10 & $\mathrm{X}$ & & & \\
\hline possibility of move away & 2 & $\mathrm{X}$ & $\mathrm{X}$ & $\mathrm{X}$ & \\
\hline freedom to choose between places & 1 & $\mathrm{X}$ & $\mathrm{X}$ & $\mathrm{X}$ & \\
\hline meeting rooms & 1 & & $\mathrm{X}$ & $\mathrm{X}$ & \\
\hline $\begin{array}{l}\text { appropriate ratio between individual and } \\
\text { community spaces }\end{array}$ & 1 & & $\mathrm{X}$ & $\mathrm{X}$ & \\
\hline chill room & 8 & & $\mathrm{X}$ & & \\
\hline community spaces & 6 & & $\mathrm{X}$ & & \\
\hline sport in the office space & 15 & & $X$ & & \\
\hline kitchen & 5 & & $\mathrm{X}$ & & \\
\hline quiet & 69 & & & $\mathrm{X}$ & \\
\hline calm & 37 & & & $\mathrm{X}$ & \\
\hline organized & 24 & & & $\mathrm{X}$ & \\
\hline possibility of concentrated work & 6 & & & $\mathrm{X}$ & \\
\hline separable & 5 & & & $\mathrm{X}$ & $\mathrm{X}$ \\
\hline personal space & 30 & & & $\mathrm{X}$ & $\mathrm{X}$ \\
\hline $\begin{array}{l}\text { enclosed office with small number of } \\
\text { employees }\end{array}$ & 11 & & & $\mathrm{X}$ & $\mathrm{X}$ \\
\hline own workstation & 2 & & & $\mathrm{X}$ & $\mathrm{X}$ \\
\hline separate tables & 1 & & & $\mathrm{X}$ & $\mathrm{X}$ \\
\hline personal items & 2 & & & & $\mathrm{X}$ \\
\hline $\begin{array}{l}\text { opportunity to manipulate the } \\
\text { environment at low cost }\end{array}$ & 1 & & & & $\mathrm{X}$ \\
\hline total & & 68 & 39 & 190 & 52 \\
\hline
\end{tabular}


such as organized (24 mentions, 2/5/6 codes) and supportive (5 mentions, 3/4/7 codes). 47 content codes received 2 Maslow codes, such as bright (128 mentions, 2/6 codes) and homy ( 8 mentions, 3/6 codes). 87 content code received only one Maslow code. The 146 content codes received 217 Maslow codes in total. We used the 8-level version of Maslowls theory. We didn't find any response referring to the transcendental need, but several did to all the other ones. In the following charts we demonstrate the distribution of the Maslow categories based on the content codes (Fig. 3) and the individual responses (Fig. 4).

\section{Discussion}

Our first important conclusion is that office workers consider the physical environment of their workplace at least as important as the social environment. The frequency and the rank of the physical environment-related answers prove their relevance to employees. The appropriate amount of light (under 3 content code) as a criteria of an excellent work environment is absolutely outstanding from the sample. The ambient stimuli in general dominated the responses. This makes us think that employees are very much aware of the importance of these variables

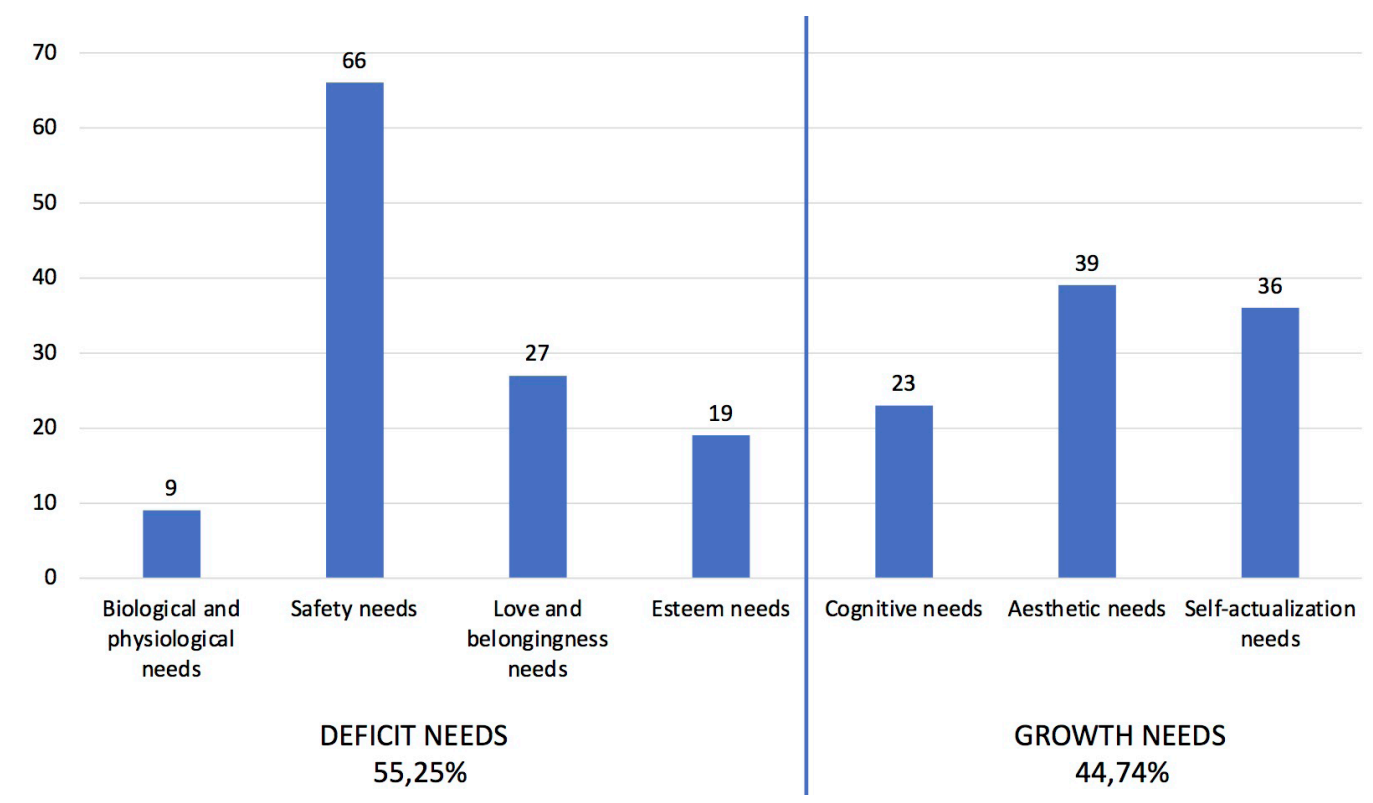

Fig. 3 Proportion of the Maslow codes among the 146 content codes (self edited)

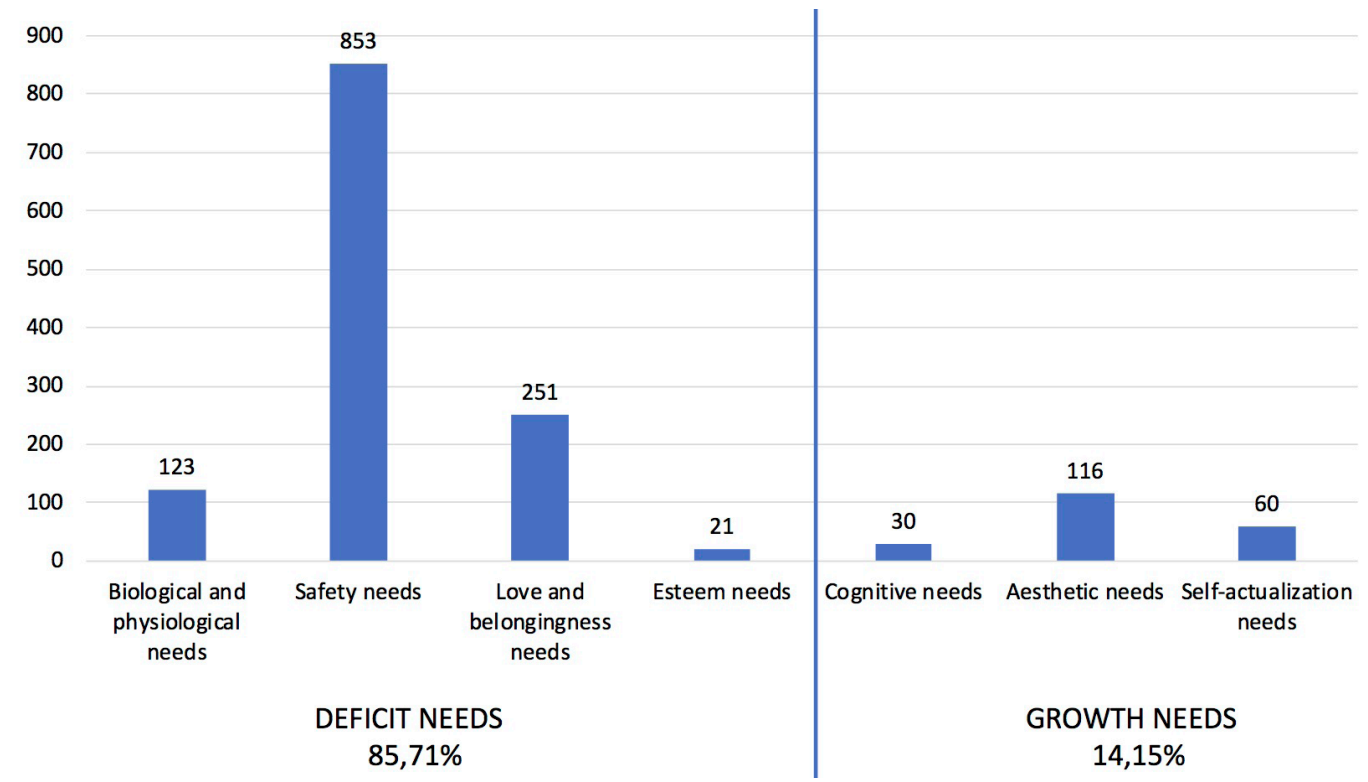

Fig. 4 Proportion of the Maslow codes among among the 1456 individual responses (self edited) 
despite psychology calling them phenomena out of awareness. Based on the literature and the changes in the labor market, we formulated some needs expected to appear in the study such as the need for space, for alternative rooms, for concentration, and for personalization. These aspects have indeed turned up among the responses in large number and in a heterogeneous way. This result confirms that having own territories in the office is important despite the emerging trend of flexible designs. We believe that the need for controlling important spaces and tools will remain essential for the employees of the future even in new generation environments. In the era of mobile devices and home office opportunity this is often questioned. For us, the most interesting element of the results was the analysis of the content codes via emotional-motivational aspects. The highest percentages of the responses were related to Maslow's security needs. In the age of workplace gamification and "super offices" this result warns everyone to start office space development by considering the fundamental aspects of it. In other words, if an organization struggles with hygienic factors, time hasn't really arrived yet to work on the possible motivators. For example, if sufficient natural light is not available, if the office is not clean enough, or if there is no space for concentrated work, social and physical environmental motivators cannot work effectively. We think that the fact that these fundamental aspects showed up with such high response rates means that employees have had bad experiences with them during their careers. We also assume that because of these possible bad experiences employees are so aware of the role of ambient stimuli. $14.15 \%$ of the responses referred to one of Maslowls growth needs, such as the cognitive, aesthetic, and self-actualization need. Based on the result, we argue that the physical environment can be differentiated along the Maslow needs, and Herzberg's two-factor theory as well. Therefore, we can consider certain physical environmental aspects as a hygiene factor, some of them as a motivator. We also highlight that most of the content codes received more than one Maslow code, in some cases a deficit need code and a growth need code as well. This means that some physical environmental aspect can be represented by more than one level from an emotional-motivational perspective. These aspects can be considered as hygiene factors and motivators as well. Take organized as an example, which received three different Maslow codes. We can consider it as a security need, where an organized environment means a transparent, safe space that we can get to know and where we do not get lost. But an organized environment can also refer to a cognitive need, a need for a space where the employee can focus and concentrate. It can also be considered as an aesthetic need, where the objects and equipment represent a coherent whole, which is visually pleasing. These multilevel content codes need further examination and analysis in order to implement them properly in practice. The strength of this qualitative questionnaire-based research with this sample size is that the ranking of the listed aspects is pretty massive. The limitation of the study lies in the subjective nature of the method. We don't know exactly what responders meant exactly by the described criteria. We also have no information why unmentioned aspects were left out: because they are really not important, or just have been forgotten because their presence is natural. It is also important to mention that the responses were surely influenced by the surrounding organisational culture, or whether the responders were lay in the subject. The large sample can partially offset these limits, but further research is absolutely necessary in this topic.

Summarizing the results, if someone would like to start a human-focused office development, the first and most important step is to fully secure all the deficit needs. These fundamental aspects may not be getting enough attention nowadays despite being necessary for an effective operation. When the hygienic factors are satisfied, motivators can really have their impact on employees. Based on the results we argue that some physical environmental elements or at least some aspects of it surely can be considered as motivators. We also want to highlight that territoriality and the need for safe and organized spaces are also seem to be very important, regardless of the office design. Employers in the future should consider the rearrangement of the office spaces as a possibility, and psychological planning should also take its place alongside architectural planning.

\section{Acknowledgement}

The authors thank Gábor Horváth and Violetta Tóth-Varga for their help in coding. 


\section{References}

Alexander, C., Ishikawa, S., Silverstein, M., Jacobson, M. FiksdahlKing, I. Angle, S. (1977) "A Pattern Language: Towns, Buildings, Construction", Oxford University Press, USA.

Altman, I. (1975) "The environment and social behavior: Privacy, personal space, territory and crowding", Brooks-Cole Publishing, Monterey, CA, USA.

Bassett-Jones, N., Lloyd, G. C. (2005) "Does Herzberg's motivation theory have staying power?", Journal of Management Development, 24(10), pp. 929-943.

https://doi.org/10.1108/02621710510627064

Brown, G., Zhu, H. (2016) "'My workspace, not yours': The impact of psychological ownership and territoriality in organizations", Journal of Environmental Psychology, 48, pp. 54-64. https://doi.org/10.1016/j.jenvp.2016.08.001

Campbell, J. M. (1983) "Ambient stressors", Environment and Behavior, 15(3), pp. 355-380. https://doi.org/10.1177/0013916583153005

Cao, M., Wei, J. (2005) "Stock market returns: A note on temperature anomaly", Journal of Banking \& Finance, 29(6), pp. 1559-1573. https://doi.org/10.1016/j.jbankfin.2004.06.028

Dúll, A. (2009) "A környezetpszichológia alapkérdései - Helyek, tárgyak, viselkedés" (Fundamental questions of environmental psychology - Places objects, behavior), L'Harmattan, Budapest, Hungary. (in Hungarian)

Dúll, A., Pálfy, S. (2014) "On Public Issues and Public Spaces - a Design Course Focusing on the Danube Bank in Budapest", Periodica Polytechnica Architecture, 45(2), pp. 47-51.

https://doi.org/10.3311/PPar.7594

Dúll, A., Urbán, R. (1997) "Az épített környezet konnotatív jelentésének vizsgálata: módszertani megfontolások" (Examining the connotative meaning of the built environment: Methodological considerations), Pszichológia, 17(2), pp. 151-179. (in Hungarian)

Dúll, A., Tauszik, K. (2006) "A munkahelyhez kötődés konstruktumának vizsgálata - Elméleti megfontolások egy tranzakcionális helykutatáshoz" (Exploring the construct of workplace attachment - Theoretical considerations for a transactional place research), Magyar Pszichológiai Szemle, 61(1), pp. 87-105. (in Hungarian) https://doi.org/10.1556/MPSzle.61.2006.1.6

Frankó, L., Dúll, A. (2017) "Az Észlelt Irodai Magánszféra Kérdőív adaptálása magyar nyelvre" (The Hungarian adaptation of the Experienced Privacy Questionnaire), Alkalmazott Pszichológia, 17(2), pp. 109-122. (in Hungarian) https://doi.org/10.17627/ALKPSZICH.2017.2.109

Frankó, L., Dúll, A. (2018) "A munkahelykötődés és a munkaállomás-kötődés konstruktumainak mérése és gyakorlati relevanciája" (Measurement and practical relevance of the workplace and workstation attachment constructs), Alkalmazott Pszichológia, 18(4), pp. 77-91. https://doi.org/10.17627\%2FALKPSZICH.2018.4.77

Heerwagen, J. H., Heubach, J. G., Montgomery, J., Weimer, W. C. (1995) "Environmental Design, Work, and Well Being: Managing Occupational Stress through Changes in the Workplace Environment", AAOHN Journal, 43(9), pp. 458-468. https://doi.org/10.1177/216507999504300904
Herzberg, F., Mausner, B., Snyderman, B. B. (1959) "The Motivation to Work", 2nd ed., John Wiley \& Sons, NewYork, USA.

Gensler Study (2013) "US Workplace Survey", [online] Available at: https://bit.ly/2TSxkxM [Accessed: 29 July 2019]

JLL Research (2019) "Flexible space evolves. Markets that are flexing their muscles in 2019", [online] Available at: https://bit.ly/2TrKsoA [Accessed: 29 July 2019]

Kaplan, S., Kaplan, R. (1989) "The Visual Environment: Public Participation in Design and Planning", Journal of Social Issues, 45(1), pp. 59-86 https://doi.org/10.1111/j.1540-4560.1989.tb01533.x

Kim, J., de Dear, R. (2013) "Workspace satisfaction: the privacy-communication trade-off in open-plan offices", Journal of Environmental Psychology, 36, pp. 18-26.

https://doi.org/10.1016/j.jenvp.2013.06.007

Laurence, G. A., Fried, Y., Slowik, L. H. (2013) "eeMy space": A moderated mediation model of the effect of architectural and experienced privacy and workspace peronalization on emotional exhaustion at work", Journal of Environmental Psychology, 36, pp. 144-152. https://doi.org/10.1016/j.jenvp.2013.07.011

Locasso, R. M. (1992) "11 - The influence of a beautiful versus an ugly room on ratings of photographs of human faces: A replication of Maslow and Mintz", In: Nasar, J. L. (ed.) Environmental aesthetics: Theory, Research, and Applications, Cambridge University Press, Cambridge, UK, pp. 134-143. https://doi.org/10.1017/CBO9780511571213.016

Maslow, A. H. (1970) "Motivation and Personality", 2nd ed., Harper and Row, NewYork, USA.

Maslow, A. H., Mintz, N. L. (1956) "Effects of Esthetic Surroundings: I. Initial Effects of Three Esthetic Conditions Upon Perceiving "Energy" and "Well-Being" in Faces", The Journal of Psychology: Interdisciplinary and Applied, 41(2), pp. 247-254. https://doi.org/10.1080/00223980.1956.9713000

Oldham, G. R. (1988) "Effect of changes in workspace partitions and spatial density on employee reactions", Journal of Applied Psychology, 73(2), pp. 253-258. https://doi.org/10.1037/0021-9010.73.2.253

Oldham, G.R., Fried, Y. (1987) "Employee reactions to workplace characteristics", Journal of Applied Psychology, 72(1), pp. 75-85. https://doi.org/10.1037/0021-9010.72.1.75

Ozguner, Z., Ozguner, M. (2014) "A Managerial Point of View on the Relationship between of Maslow's Hierarchy of Needs and Herzberg's Dual Factor Theory", International Journal of Business and Social Science, 5(7), pp. 207-215.

Parde, R. L. (1990) "Motivation Theories of Maslow, Herzberg, McGregor \& McClelland. A Literature Review of Selected Theories Dealing with Job Satisfaction and Motivation. [pdf] Available at: https:// files.eric.ed.gov/fulltext/ED316767.pdf [Accessed: 29 July 2019]

Salama, A. M., Courtney, L. (2013) "The impact of the spatial qualities of the workplace on architects' job satisfaction", ArchNet International Journal of Architectural Research 7(1), pp. 52-64.

Sykes, E. R. (2001) "Interruption in the workplace: A case study to reduce their effects", International Journal of Information Management, 31(4), pp. 385-394. https://doi.org/10.1016/j.ijinfomgt.2010.10.010 
Tay, L., Diener, E. (2011) "Needs and Subjective Well-Being Around the World", Journal of Personality and Social Psychology, 101(2), pp. 354-365.

https://doi.org/10.1037/a0023779

Veitch, J. A., Charles, K. E., Farley, K. M. J., Newsham, G. R. (2007) "A model of satisfaction with open-plan office conditions: COPE field findings", Journal of Environmental Psychology, 27(3), pp. 177-189. https://doi.org/10.1016/j.jenvp.2007.04.002

Vischer, J. C., Wifi, M. (2017) "The Effect of Workplace Design on Quality of Life at Work", In: Fleury-Bahi, G., Pol, E., Navarro, E. (eds.) Handbook of Environmental Psychology and Quality of Life Research, Springer, Cham, Switzerland, pp. 378-400. https://doi.org/10.1007/978-3-319-31416-7_21
Wells, M. M. (2000) "Office clutter or meaningful personal displays: the role of office personalization in employee and organizational well-being", Journal of Environmental Psychology, 20(3), pp. 239-255.

https://doi.org/10.1006/jevp.1999.0166

Fox, B. (2019) "2019 Workplace Trend Predictions", Work Design Magazine, [online] 31 January 2019. Available from https://bit. ly/2REGojF [Accessed: 29 July 2019]

Yildirim, K., Akalin-Baskaya, A., Celebi, M. (2007) "The effects of window proximity, partition height, and gender on perceptions of open-plan offices", Journal of Environmental Psychology, 27(2), pp. $154-165$.

https://doi.org/10.1016/j.jenvp.2007.01.004 